\title{
高強度繊維の異方性弾性定数と強度 TOPICS
}

繊維は一般に高分子鎖が繊維軸方向に強く配向する ためその力学的性質に強い異方性が生じている．通常 は纎維軸に対して軸対称の異方性をもつと考えられ， 線形弾性体としてこの異方性弾性体を記述する弾性定 数は次の 5 つである.

$E_{\mathrm{L}} ;$ 繊維軸方向の弾性率

$E_{\mathrm{T}}$; 繊維軸に直角方向の弾性率

$G_{\mathrm{LT}} ;$ 䌩維軸をるじるときのトルクに関係するせん断 弾性率

$\nu_{\mathrm{LT}}$; 繊維軸方向の一軸伸長における伸長ひずみとそ れに伴う直角方向のひずみで定義されるポアソ ン比

$\nu_{\mathrm{TT}} ;$ 繊維軸に直角の断面内でのポアソン比

これら 5 つのパラメータが繊維の性質を与えるが, 纎維は必ずしも線形挙動のみでなく非線形の挙動を示 し，また粘弾性あるいは塑性を示す．したがって，瀻 維の性質をとらえるにはこれら5つのそれぞれについ ての挙動を詳しく観測する必要がある.

しかし，これまで実用化されている織維についてこ れら性質がすべて明らかになっているわけでなく，主 に $E_{\mathrm{L}}$ ，わずかに $G_{\mathrm{LT}}$ がわかっているにすぎない。こ の不完全な状況のもとで繊維を多くの用途に応用し, また繊維の内部構造を論じているのが現状である。緎 維の強度についても繊維軸方向のみでなく, 直角方向 やせん断変形に対する強度も必要で，特に複合材料の 強度設計にはこれらが重要である。最近，われわれは 上記の 5 つの特性を評価するための測定システムを完 成させ，単繊維を直接に測定することにより外乱を排 除してこれら特性を純粋に求めることができるように なった ${ }^{1), 2}$. ただし $\nu_{\mathrm{TT}}$ は一軸に配向した瀻維高充て んコンポジットを用いて測定する，高強度繊維を含む

表 1 瀻維の弾性定数 ( 2 例)

\begin{tabular}{ccccc}
\hline \multicolumn{5}{c}{ アラミド繊維 “Kevlar 49” } \\
\hline$E_{\mathrm{L}}(\mathrm{GPa})$ & $E_{\mathrm{T}}(\mathrm{GPa})$ & $G_{\mathrm{LT}}(\mathrm{GPa})$ & $\nu_{\mathrm{LT}}$ & $\nu_{\mathrm{TT}}$ \\
$129.6 *$ & 2.49 & 2.01 & 0.62 & 0.31 \\
$(113.4)$ & \multicolumn{5}{c}{} \\
\hline \multicolumn{5}{c}{ 炭素緎維 “Torayca T300” } \\
\hline$E_{\mathrm{L}}(\mathrm{GPa})$ & $E_{\mathrm{T}}(\mathrm{GPa})$ & $G_{\mathrm{LT}}(\mathrm{GPa})$ & $\nu_{\mathrm{LT}}$ & $\nu_{\mathrm{TT}}$ \\
$308.1 *$ & 6.03 & 18.24 & 1.05 & 0.31 \\
$(234.6)$ & \multicolumn{5}{c}{} \\
\hline
\end{tabular}

* : 破断付近の值，（）内は初期低ひずみ域での值

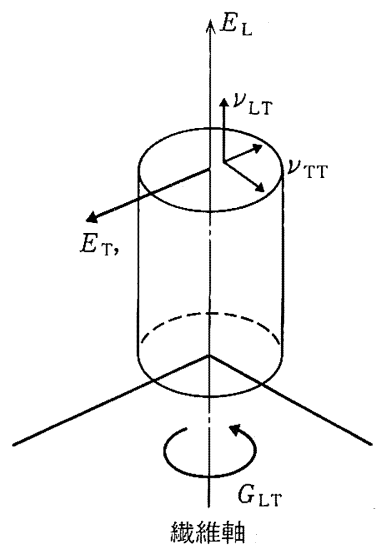

図 1 繊維の性質を記述する弾性定数

多くの繊維について測定を進めているが, これまでに 明らかになったことをまとめると，

(1) $E_{\mathrm{L}} / E_{\mathrm{T}}$ 比（異方性パラメー夕）は衣料用のポ リエステル瀻維で 8 18, 高強度繊維の Kevlar 149 では 84 , 高強度ポリエチレン繊維で 74 のようにきわ めて強い異方性を示す。

（2）一般に有機繊維では $E_{\mathrm{T}}$ および $G_{\mathrm{LT}}$ に塑性によ る降伏現象が現れ, 弾性範囲は狭い. 降伏応力も降伏 現象を示さない炭素瀻維やセラミック瀻維のこれら変 形における破壊強度に比較して低く，それらの1/50 程度である。

信頼性の要求される高強度材料や微妙な触感が要求 される高品質衣料材料の設計には上に示した繊維特性 のすべてについて知ることが重要で, 高い $E_{\mathrm{L}}$ 值の競 争に走り，バランスの失った纎維を開発してもその用 途に困るはずである。

\section{文 献}

1) S. Kawabata: Proceedings of the 4th Japan-US Conference on Composite Materials at Washington DC., Technomic, (1989) p.25

2) S. Kawabata: Journal of the Textile Institute, 81, 432 (1990)

川端 季雄 Sueo Kawabata（京都大学工学部高分 子化学教室 - 教授, 工博, 専門=高分子固体力学, 繊 維状材料物性) 